УДК 633.1:631.582.3(09)

(C) 2012

Ряба О. І., кандидат історичних наук

Національний університет біоресурсів і природокористування України

\title{
ІСТОРІЯ ВИНИКНЕННЯ ТА ЕВОЛЮЦІЇ ПОЛІПШЕНОЇ ЗЕРНОВОЇ СИСТЕМИ ЗЕМЛЕРОБСТВА
}

\section{Рецензент - доктор сільськогосподарських наук Г. І. Демидась}

\begin{abstract}
Здійснений иілісний, історико-науковий, неупереджений, глибокий $і$ всебічний аналіз проиесу $і$ причин переходу від парової (парозернової) й вигінної (багатопільно-трав'яної) систем землеробства до поліпшеної зернової. Показана роль багатовікової хліборобської практики і культурно-господар-

ського розвитку, внесок вчених в удосконалення $i$ впровадження в землеробську практику більш прогресивних і адаптивних до трунтово-кліматичних умов систем рільництва. Акиентовано увагу на історичній необхідності розвитку обох галузей сільськогосподарського виробництва - рослинництва і тваринництва - за перехідних систем землеробства. Доведено, щзо творием поліпшеної зернової системи землеробства є В. О. Левшин.
\end{abstract}

Ключові слова: історія, еволючія, система землеробства, сівозміна, корми, тваринництво.

Постановка проблеми. У нашій країні ще 3 часів стародавньої Русі аж до початку XX ст. існувала парова система землеробства 3 трипільною сівозміною: перше поле - пар, друге - жито озиме, а на півдні - пшениця озима, трете - «сірі» ярі хліба (ячмінь, овес, гречка), за якої були цілком знищені продуктивні пасовища 3 їх багаторічною трав'янистою рослинністю.

У лісо-лучній зоні під пасовища використовувалися ліси водоохоронної зони з їх розкішною трав'янистою рослинністю на освітлених місцях. Тварини тут поїдали траву, а разом із нею і молоду деревну поросль, тим самим знищуючи ліси. Землі з-під них розорювали, поверхня грунту під впливом атмосферних опадів зазнавала ерозії, збільшувалася площа під ярами, замулювались і міліли русла річок, що неминуче призводило до їх пересихання.

Зменшення площі перелогових земель, розорювання лук за парової системи різко погіршили кормову базу тваринництва, яке й до того було малорозвиненим. Хоча парові поля і використовувалися під пасовища, проте це не вирішувало справи. По-перше, тварини не одержували достатньо кормів, а по-друге, значно погіршувалися агрофізичні властивості грунту парового поля від тривалого перебування на ньому худоби.
Такий пар у народі справедливо називали «толокою» [11].

Аналіз останніх досліджень і публікацій, у яких започатковано розв'язання проблеми. Подальший розвиток парової системи вивчений недостатньо і потребує всебічного дослідження. В історичній i агрономічній науках відсутній глибокий аналіз причин виникнення та еволюції поліпшеної зернової системи, яка й по сьогодні частково застосовується на півдні України. Історія землеробства показала, що пар без добрив (окрім того ж ще й пізній, оскільки на ньому пасли худобу) не став засобом відновлення родючості грунту та очищення його від бур'янів. Гній на добриво в Росії, зазвичай, не використовували до кінця XIX ст., а якщо й використовували, то рідко (раз у 6-9 років) і невеликими дозами. Внаслідок цих причин середня урожайність зернових культур за парової системи була низькою $\mathrm{i}$ нестійкою: в XVIII ст. вона коливалася в межах 5-7 ц/га [9]. У тих же небагатьох господарствах, де гній вносили регулярно (раз у три роки), пари орали рано, дотримувались інших елементарних агротехнічних вимог, - і за парової системи отримували цілком задовільні для того часу врожаї [10]. Однак і за дотримання агротехнічних вимог парова система мала два суттєвих недоліки: пари займали багато ріллі (зазвичай $1 / 3-$ $1 / 2$ ) і не було посівів кормових культур. Виробництво кормів базувалося виключно на використанні бур'янів парових полів і природних кормових угідь, які не поліпшувалися й були малопродуктивними. Постійна нестача кормів практично означала неможливість підвищення продуктивності тваринництва, яке отримало назву гнойового [1].

Мілка оранка земель і вирощування лише хлібних злаків спричинили в окремих районах ерозійні процеси.

Якщо багаті на чорноземні грунти губернії мали можливість тривалий відрізок часу вести рослинництво за парової системи без застосування добрив, то в нечорноземній смузі це виключалося: на дерново-підзолистих грунтах 
обов'язково необхідно було вносити гній під пар один раз у три роки.

Невеликі норми гною, які вносили тоді, не могли істотно підвищити родючість грунту. Дерново-підзолисті грунти 3 кожним роком виснажувалися, врожаї були стихійні й цілком залежали від погодних умов та фітосанітарного стану полів.

У XVII-XVIII ст. у деяких країнах Західної Європи і в окремих маєтках російських поміщиків робляться спроби покращити парову систему. Ріст населення, розвиток торгівлі, загарбницькі війни вимагали від сільського господарства більшої кількості різноманітної продукції. Наслідком стала поступова зміна структури посівів, впровадження нових культур (багаторічні трави, коренеплоди і картопля). Скорочувалися площі під чистим паром, розорювались малопродуктивні луки [8].

Мета досліджень - здійснити цілісний історико-науковий, неупереджений, глибокий і всебічний аналіз причин виникнення та еволюції поліпшеної зернової (парозернової) системи землеробства та 3'ясувати роль вчених і практиків у їі становленні й розвитку.

Методи досліджень. Методологічною основою дослідження обрано історико-науковий, діалектико-логічний, бібліографічно-статистичний, проблемно-хронологічний методи, які сприяли комплексному аналізу предмета дослідження, що грунтується на принципах історизму, багатофакторності, всебічності та наукової об'єктивності пізнання.

Результати досліджень. У Росії заміна парової системи відбувалася в районах, де розвивалося молочне тваринництво або впроваджувалися посіви технічних культур (переважно у поміщицьких господарствах). Тут виникли різноманітні форми більш інтенсивного землеробства із застосуванням польового травосіяння. У поміщицьких бурякосіючих господарствах нерідко застосовували сівозміни плодозмінної системи. У селянських господарствах парова система змінювалася поліпшеною зерновою 3 впровадженням травосіяння в нечорноземній смузі й посівів просапних культур (кукурудзи, соняшнику) в чорноземній зоні. Сівозміни поліпшеної зернової системи впроваджувались у країні до 30 -х років ХХ століття.

Вигінна система також поступово переходила в поліпшену зернову шляхом скорочення частки багаторічних трав і збільшення зернових культур.

Включення одного або двох полів пару в сіво- зміну багатопільно-трав'яної системи і відповідне скорочення «трав'яного періоду», вказує О. С. Єрмолов (1846-1916), перетворює ï в поліпшену зернову систему [3], за якої вирощування кормових трав і утримання худоби мають за мету тільки збільшення гною та підвищення урожайності хлібів. Однак зазвичай поліпшена зернова система $\epsilon$ результатом удосконалення парової системи, коли трипільна сівозміна перетворюється в чотирипільну - пар, озимі, ярі, трави або пар, озимі, трави, ярі.

Поліпшена зернова система (повністю або частково) широко використовувалась у землеробстві Нечорноземної зони. У зернопаротрав'яних сівозмінах зернові культури займали від половини до 2/3 рілл; $15-25$ \% ії відводилося під чисті пари і 20-30 \% - під багаторічні трави. Просапних і зернобобових культур не було або вони займали незначні площі. Родючість грунту підтримувалася вирощуванням багаторічних трав, паровим обробітком i застосуванням добрив, передусім гною [11]. Поліпшені зернові сівозміни з багаторічними травами послужили прообразом польових травопільних сівозмін [12].

У чорноземних районах Росії парова система поліпшувалася шляхом впровадження посівів цукрових буряків, соняшнику, кукурудзи та інших просапних культур. Таких же змін зазнавала парова система в районах розвинутого картоплярства Нечорноземної зони [7].

Підвищення урожайності полів у чорноземній i особливо в нечорноземній смузі Росії в кінці XVIII - на початку XIX ст. практично упиралося в розвиток скотарства - власне, єдиного на той час джерела удобрення грунту, а розвиток тваринництва, у свою чергу, - в нестачу кормів. Тому вітчизняна агрономічна думка тих часів настійливо шукала раціональних способів підвищення ефективності травосіяння і продуктивності сівозмін [13].

3'явилася поліпшена зернова система в Росії на початку XIX ст. і була нерозривно пов'язана 3 ім'ям В. О. Левшина (1746-1826) - основоположника вчення про травосіяння в Росії й творця поліпшеної парової системи землеробства, що увійшла в сільськогосподарську літературу XIX ст. під назвою «поліпшеної зернової системи» i найбільш широко застосовувалася в селянських господарствах Московської та Ярославської губерній.

На відміну від А.Т. Болотова (1738-1833), який обмежив свої досліди щодо травосіяння городньою ділянкою [2], В. О. Левшин переніс дослідне травосіяння на поля. Він наголошував, 
що «земледелие не может быть исправно» там, де кормів для худоби не вистачає і скотарство погане [4].

Перебороти ж нестачу кормів і занепад скотарства можна було, на переконання В. О. Левшина, перш за все шляхом травосіяння на луках $\mathrm{i}$ полях. Однак для цього необхідно було попередньо зайнятися вивченням поживних для худоби дикоростучих трав і дослідним травосіянням у польових та лучних умовах. Другим серйозним мотивом до вивчення дикоростучих трав і травосіяння став патріотичний порив В. О. Левшина «доказать о ненужности выписывать из других стран и платить деньги за те семена, которые с рачением можно набрать дома» [4].

Виступаючи проти застосування сівозміни Йогана Шубарта в південній смузі, В. О. Левшин пропонував виключити конюшину і замінити іï люцерною. Він вказує, що «из посевных трав люцерна может быть выгоднее других, так как выдерживает жару и засуху ... В южных районах люцерна есть почти единственная трава, могущая быть наиболее свойственной» [5].

Левшин В. О. був рішуче не згоден і з тим, що «системою Шубарта» не передбачалося створення штучних луків поза сівозміною. Відкинувши сівозміну Шубарта, він запропонував для південних районів Росії свою чотирипільну сівозміну: 1 - озимі, 2 - ярі з травами, 3, 4 - трави на укіс.

Як і І. М. Комов та А. Т. Болотов, В. О. Левшин добре усвідомлював, що пануюча в Росії парова система перетворилась у свою протилежність, - стала за умов крайньої недостачі луків i вигонів, худоби і гною не способом відтворення родючості грунту, а способом його розкрадання. Тому він зосередив свої зусилля не на розробці нової, більш досконалої системи, а на поліпшенні старої - парової. Його насамперед турбувало питання про зростання кількості й поліпшення якості кормів, збільшення поголів'я худоби та виробництва гною за існуючої системи землеробства. Позитивне вирішення цього питання мало повернути паровій системі колишнє значення як способу відтворення родючості грунту. В польовому травосіянні за існуючої парової системи В. О. Левшин вбачав ключ до вирішення цього питання.

Однак, як впровадити травосіяння в через смугових володіннях із паровою системою, де худоба пасеться на пару? Це можна зробити, - вказував В. О. Левшин, - трьома простими шляхами: організацією «углового» травосіяння, травосіянням на «задах» і впровадженням наступної сіво- зміни: перше поле - пар, друге - озимі, третє ярі, четверте - трави. Таку чотирипільну сівозміну він запровадив у своєму маєтку Термяк Белевського повіту Тульської губернії й невдовзі на власному досвіді переконався в їі корисності: поліпшилася кормова база господарства, підвищилась урожайність хлібів.

Сівозміна В. О. Левшина пройшла тривалу еволюцію i, нарешті, поширилася не тільки в поміщицьких, але й у селянських господарствах центральних губерній нечорноземної смуги. У 1805 р. дрібний поміщик I. I. Самарін (17741847) впровадив цю сівозміну у своєму маєтку Івахово Романівського повіту Ярославської губернії і в господарствах своїх селян. Переконавшись у їі вигідності, I. I. Самарін у 1816 р. впроваджує дану сівозміну і в другому своєму маєтку - Конищево, розташованому в 20-ти верстах від Івахово.

У 1826 р. у «Земледельческом журнале» (№16) була надрукована стаття князя С. Гагаріна «Замечания на статью г. Самарина о травосеянии», в якій він рекомендував сіяти конюшину не по ярому хлібу, а по житу ранньої весни. Цю пропозицію I. I. Самарін із вдячністю прийняв i запровадив наступне чергування культур: перше поле - пар, друге - озимина 3 підсівом конюшини, третє - конюшина, четверте - ярі. За його прикладом, чотирипільну сівозміну 3 конюшиною запровадила в себе і у своїх селян переважна частина сусідів та багато поміщиків інших повітів Ярославської губернії.

Першим вогнищем масового травосіяння в Роciï були Ярославська i Московська губернії. Починаючи 3 20-х років XIX ст., трави сіяли тут переважно в чотирипільній сівозміні: 1 - пар, 2 - озимі, 3 - конюшина, 4 - ярі; значно рідше у зерновому трипіллі. В останньому випадку кожне із трьох полів ділили пополам і половину поля займали конюшиною дворічного використання, внаслідок чого фактично отримували шестипільну сівозміну: 1 - пар, 2 - озимі, 3, 4 - конюшина, 5 - озимі, 6 - ярі.

Щоб запобігти у чотирипільній сівозміні конюшиновтоми грунту, селяни Ярославської губернії вже в кінці 40-х років ХІХ ст. стали ділити на дві половини кожне із чотирьох полів і засівати сумішкою конюшини 3 тимофіївкою лише половину поля, але для дворічного використання. Так виникло відоме ярославське чотирипілля 3 восьмирічним чергуванням культур: 1 - пар, 2 - озимі, 3, 4 - трави, 5 - ярі, 6 - пар, 7 - озимі, 8 - ярі. Пізніше аналогічна сівозміна виникла і в селянських господарствах Волоколамського 
повіту Московської губернії [13].

Другим вогнищем травосіяння в Росії стала Тверська губернія, особливо іiі Зубцовський повіт. Ініціатором посівів трав на полях був відомий діяч сільського господарства, автор багатьох праць, поміщик Д. П. Шелехов. У своєму маєтку Фролово він запровадив таку семипільну сівозміну: 1 - вика по свіжому гною; 2 - жито; 3 - горох і вика на насіння; 4 - коренеплоди по гною на одній половині поля, вика на зелений корм худобі - на другій; 5 - ячмінь із підсівом конюшини; 6 - конюшина на один укіс; 7 - пшениця.

У другому маєтку Д. П. Шелехова (Аполлоновськ) була запроваджена наступна сівозміна: 1 - вика по свіжому гною, 2 - жито 3 підсівом конюшини, 3 - конюшина на один укіс, 4 - гоpox, 5 - овес, 6 - коренеплоди і вика по гною на зелений корм, 7 - ячмінь і пшениця.

Впровадження нових сівозмін, як зауважував свого часу Д. П. Шелехов, дало змогу збільшити виробництво кормів, гною, хліба, поголів'я худоби, поліпшити обробіток грунту.

Історичний процес перетворення заліжної системи в парову, парової - в поліпшену зернову i поліпшеної зернової - в плодозмінну, як вказував О. П. Людоговський (1840-1882), стосується європейських країн із континентальним кліматом, нечорноземними глинистими та суглинковими грунтами й недостатньою кількістю природних луків, необхідних для підтримання родючості грунту. Виняток із цього правила становили господарства, що мали великі площі природних, особливо заливних луків, а також піщаних сухих грунтів. Перші довше звичайного продовжували триматися парової системи, а далі, обминувши поліпшену зернову систему, перейшли безпосередньо до плодозміни, перетворившись у господарства тваринницького напряму. Другі від зернового трипілля перейшли до вигінної системи, а від неї - до плодозміни [6].

$\mathrm{У}$ перші роки виникнення польового травосіяння, як вказував О. П. Людоговський, із метою уникнення ламання трипільного господарства, турбувалися звичайно, щоб не зменшити площі під хлібом (67\%) і зберегти попередній поділ полів; тому початкові досліди щодо впрова-

\section{БІБЛІОГРАФІЯ}

1. Адаптивні системи землеробства / Гудзь В. П., Присак І.Д., Рибак М.Ф. [та ін.]; за ред. В. П. Гудзя. - К. : Центр учбової літератури, 2007. $-336 \mathrm{c}$.

2. Болотов A. T. О разделении полей / А. Т. Бо- дження польового травосіяння проводилися майже всюди на паровому полі або певній його частині. Звідси система й отримала назву «поліпшеної зернової».

\section{Висновки:}

1. Поліпшена зернова система виникла в результаті удосконалення парової і вигінної. Сівозміни поліпшеної зернової системи являють собою зернове трипілля, доповнене полем багаторічних трав.

2. В. О. Левшина по праву вважають піонером дослідного польового травосіяння в Росії і творцем поліпшеної зернової системи, а Д. М. Полторацького, який вперше запровадив плодозмінну сівозміну, й I. I. Самаріна, який удосконалив сівозміну В. О. Левшина, - засновниками польового травосіяння у великих господарських масштабах.

3. Сівозміни В. О. Левшина, С. І. Гагаріна й I. I. Самаріна, ярославських i волоколамських селян - така еволюція травосіяння в центральнонечорноземних губерніях Росії. Вона відбувалась у рамках парової системи і перетворила ії в більш досконалу, так звану, поліпшену зернову систему.

4. О. П. Людоговський довів, що поліпшена зернова система виникла із зернового трипілля разом $з$ упровадженням польового травосіяння. Він описав початкову форму цієї системи, яка була в ті часи (завдяки зусиллям Шубарта) розповсюджена в Німеччині, ставши перехідною формою від парової системи до плодозмінної. У своєму початковому вигляді поліпшена зернова система відрізнялася від зернового трипілля тільки паровим полем, зайнятим кормовими травами.

5. У царській Росії, особливо в Нечорноземній зоні, певне розповсюдження одержали сівозміни поліпшеної зернової системи 3 конюшиносіянням, зокрема, ярославське чотирипілля і волоколамське восьмипілля. Такі сівозміни не можна віднести до плодозмінних, оскільки в них відсутні посіви просапних і в наявності $є$ пар, але водночас вони відрізняються й від сівозмін парової системи наявністю полів багаторічних трав і технічної культури (льону).

лотов // Тр. Вольного эконом. общества. - СПб., 1771. - $177 \mathrm{c}$.

3. Ермолов A. C. Организация полевого хозяйства. Системы земледелия и севообороты : Издание пятое, пересмотренное и значительно допо- 
лненное / А. С. Ермолов. - СПб. : Изд. А. Ф. Девриена, 1914. - 719 c.

4. Левшин В. А. Описание об открытых в Тульской губернии кормовых травах / В. А. Левшин // Новое продолжение Трудов Вольного экономического общества. - Ч. 2. - СПб., 1796. - С. 4-13. 5. Левшин В. А. О заселении степей / В. А. Левшин // Новое продолжение Трудов Вольного экономического общества. - Ч. 3. - СПб., 1798. C. $208-216$.

6. Настольная книга для русских сельских хозяев / Сост. А. П. Людоговский, И. А. Стебут, И. Н. Чернопятов. - СПб. : Изд. А. Ф. Девриена, 1876. T. 2. $-450 \mathrm{c}$.

7. Павлюк С. П. Традиційне хліборобство України: агротехнічний аспект / С. П. Павлюк. - К.: Наукова думка, 1991. - $223 \mathrm{c.}$

8. Петриченко В. Ф. Сучасні системи землеробства України / В. Ф. Петриченко, Я. Я. Панасюк. - Вінниця : ФОП Данилюк В. Г., 2009. - 256 с.

9. Примак I. Д. Історичні аспекти формування екстенсивних систем землеробства в Україні / І. Д. Примак, О. І. Примак // Вісник Білоцерківського державного аграрного університету: Зб. наук. праць. - Біла Церква, 2007. - Вип. 50. C. 5-13.

10. Примак O. I. Еволюція формування системи органічного удобрення в Україні / О. І. Примак // Вісник Степу : Наук. зб. - Вип. 7. - Кіровоград : КОД, 2010. - С. 16-21.

11. Системи землеробства: історія їх розвитку $\mathrm{i}$ наукові основи / Примак І. Д., Вергунов В. А., Рошко В. Г. [та ін.]; за ред. І. Д. Примака. - Біла Церква, 2004. - 528 с.

12. Танчик С. П. До питання виникнення та становлення травопільної системи землеробства / С. П. Танчик, О. І. Ряба // Біоресурси і природокористування : Науковий журнал. - Том. 3. № 1-2, 2011. - С. 68-76.

13. Яхінсон I. 3 історії хліборобської культури / I. Яхінсон. - К. : Державне видавництво України, 1926. $-216 \mathrm{c}$. 